\title{
DETERMINATION OF XANTHOPHYLLS COMPOUNDS IN DIETARY SUPPLEMENTS BY HPLC-PDA
}

\author{
Mac Thi Thanh Hoa', Nguyen Thi Hong Ngoc, Duong Thi Mai Hoa, Cao Cong Khanh \\ National Institute for Food Control
}

(Received on: 5/3/2019; Revised on: 1/5/2019; Accepted on: 10/5/2019)

\section{Abstract}

n HPLC method using photodiode array detector (PDA) detector has been developed for the Adetermination of astaxanthin, lutein, and zeaxanthin in dietary supplements. These compounds were separated on a C30 chromatography column with ethyl acetate: acetonitrile $(12: 88, \mathrm{v} / \mathrm{v})$ containing $0.1 \% \mathrm{n}$-decanol as the mobile phase. Xanthophyll compounds, usually existing in the form of esters, were saponified in $45 \% \mathrm{KOH}$ solution (with lutein and zeaxanthin) and $1 \%$ (with astaxanthin) at $60^{\circ} \mathrm{C}$ within 15 minutes, then re-extracted with n-hexane before analyzing on HPLC system. The method was validated and had good specificity and selectivity. The linear calibration curve in the range of $0.5-10 \mu \mathrm{g} / \mathrm{ml}$, the repeatability and the recovery of the method meet the analytical requirements according to $\mathrm{AOAC}$; the method was applied to analyze several dietary supplements collected from market.

Key words: xanthophyll, lutein, zeaxanthin, astaxanthin, dietary supplement, HPLC

\section{INTRODUCTION}

Xanthophylls, a class of oxygen-containing carotenoid pigments, are responsible for the color of the yellow, orange and red hues of flowers, fruits, vegetables (corn, pepper, etc.), egg yolk, feather, shells, or flesh of many animal species (shrimp, lobster, chicken or salmon). These substances are good sources of nutritional supplements. Based on its powerful antioxidant activity, xanthophylls are used more and more frequently in supplements, dietary supplement, and cosmetics with such benefits as anti-aging, skin protection, skin beauty or eye protection and prevention of diseases related to retinal macular degeneration [1]. Several common substances in this group are lutein, zeaxanthin, astaxanthin, canthaxanthin, capsanthin, citranaxanthin and ethyl ester of $\beta$-apo-8'carotenoic acid. Due to the current popularity and application, astaxanthin, lutein and zeaxanthin (Figure 1) were selected for this study.

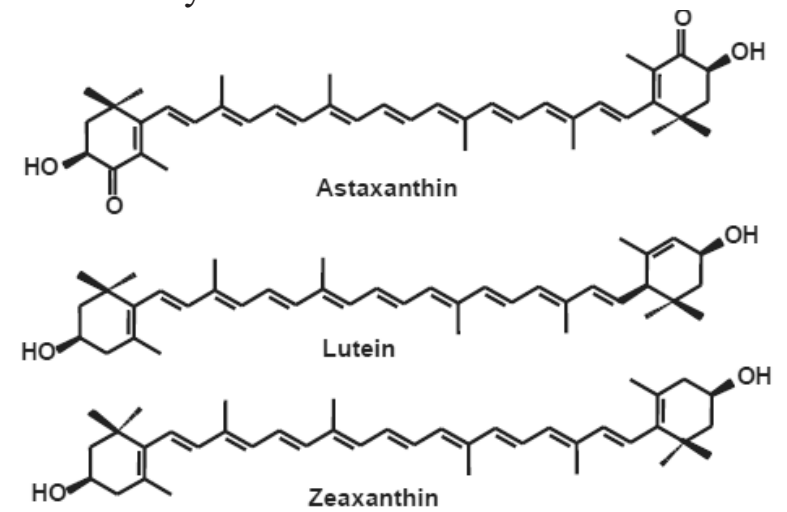

Figure 1. Chemical structure of Astaxanthin, Lutein and Zeaxanthin

${ }^{1}$ Tel:0949934881 Email: thithanhhoa.mac@gmail.com


Lutein (Lut) and zeaxanthin (Zea) are extracted from the marigold (Tagetes erecta) [2] and astaxanthin (ATX) is originated from the green microalgae Haematococcus pluvialis, yeast Phaffia rhodozyma or krill oil Euphausia superba [3]. They are added to dietary supplement in different pharmaceutical forms (hard-cover capsules, soft-cover capsules, tablets, powders) as a single component or in combination with several other active ingredients such as vitamins, herbal extracts or fatty acids to suit the uses.

Currently, studies in Vietnam rarely concern to simultaneously identify the xanthophyll compounds in dietary supplements. This makes it difficult to manage and monitor the quality of xanthophyll compounds in these products. Therefore, in order to protect consumers' rights, as well as to assist the authorities in control of food safety and quality, this study examined and evaluated an analysis method for determination of xanthophyll active ingredients (including lutein, zeaxanthin and astaxanthin) in dietary supplements. The simple and highly effective HPLC using reversed-phase separation column and PDA detector was selected in this study.

\section{SUBJECTS AND RESEARCH METHODS}

- Study subjects: Dietary supplements containing xanthophyll active substances (Astaxanthin, Lutein and Zeaxanthin) were randomly collected from Hanoi market.

- Tools and equipment:

- High performance liquid chromatography system (HPLC) of Alliance model includes high-pressure pump, column thermostat, auto-injector connecting with PDA detector of Waters brand;

- Acclaim C30 Column ( $250 \mathrm{~mm}$ x $4.6 \mathrm{~mm}, 5 \mu \mathrm{m})$ and corresponding guard column (Thermo Fisher Scientific);

- Tools and other auxiliary equipment in the laboratory.

- Chemicals, standards:

- The chemicals are all analytically pure substances;

- Lutein and Astaxanthin standards were purcharsed from Biopurify Phytochemical brand, Zeaxanthin standard was purcharsed from Chromadex brand;

- Potassium hydroxide $(\mathrm{KOH})$, ascorbic acid, tetrahydrofuran (THF), butylated hydroxytoluene (BHT), ethyl acetate, tert-butyl methyl ether (MTBE), dichloromethane (DCM), methanol $(\mathrm{MeOH})$, and acetonitrile (ACN) HPLC grade were purcharsed from Merck;

- Double distilled water.

\section{RESULTS AND DISCUSSION}

\subsection{Analysis conditions}

\subsubsection{Chromatographic conditions}

According to reference document [4] and preliminary experiments, the mobile phase ethyl acetate (acetonitrile (12: 88) (containing 0.1\% n-decanol)) was found to be suitable for the best separation of ATX, Lut and Zea. The chromatography conditions were chosen as follows:

- Acclaim C30 Column (250 mm x $4.6 \mathrm{~mm}, 5 \mu \mathrm{m})$ and corresponding guard column

- Mobile phase: ethyl acetate: acetonitrile (12: 88) (containing 0.1\% n-decanol)

- Flow rate: $1.0 \mathrm{ml} / \mathrm{min}$

- Sample injection volume: $10 \mu 1$

- Wavelength detection: $474 \mathrm{~nm}$.

\subsubsection{Sample preparation}

In nature, xanthophylls usually exist in ester form with fatty acids, therefore, saponification was required to convert them to free form. Because these compounds are very sensitive to light, temperature and $\mathrm{pH}$, it was recommended to optimize the sample preparation procedure as well as increase extraction efficiency. Alkaline solution concentration, time and temperature of saponification were examined.

A soft capsule form containing Lut, Zea and ATX was select for the study. 


\subsubsection{Alkaline solution concentration}

According to reference documents [4], ATX good recovery was achieved when using low concentration of alkaline solution while higher recovery of Lut and Zea could be obtained when using high concentration of alkaline solution. Therefore, different $\mathrm{KOH}$ solution concentrations (from 0.1 to $2 \%$ for ATX saponification and from 35 to $55 \%$ for Lut and Zea saponification) were applied within 15 minutes at $60^{\circ} \mathrm{C}$. A dietary supplement was selected as a test sample. The correlation between the concentration of $\mathrm{KOH}$ solution and the peak area of substances was presented in Figure 2.

Figure 2. Effect of KOH concentration on peak area of xanthophyll
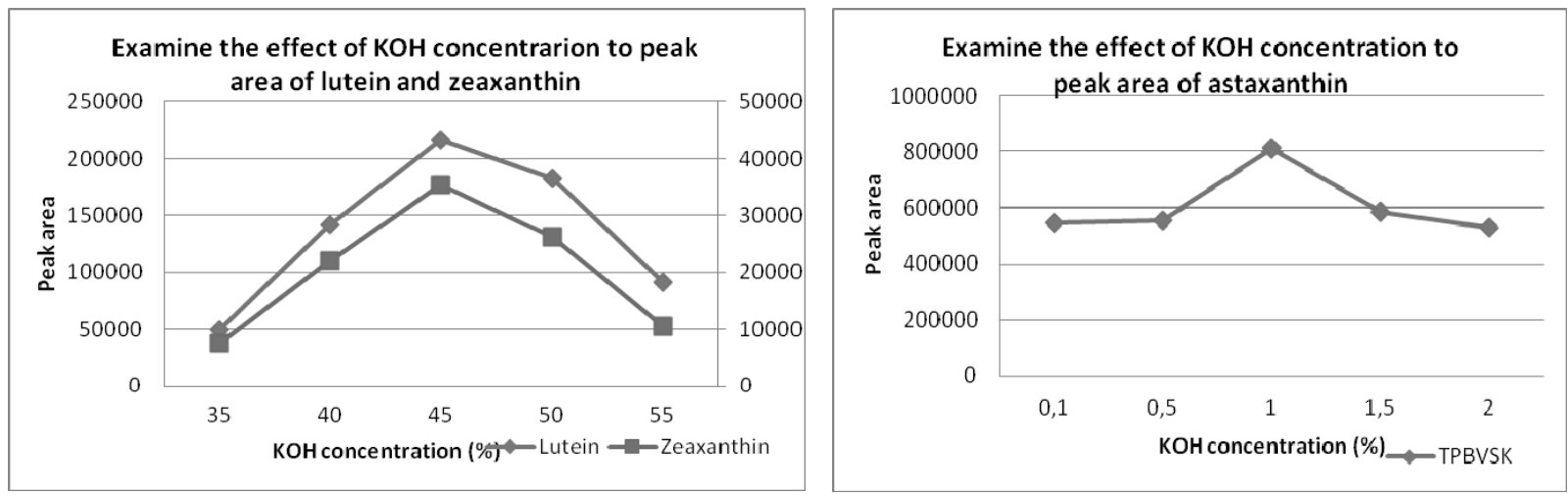

The results showed that highest recovery of Lut and Zea was achived when using $45 \% \mathrm{KOH}$ solution while the $1 \% \mathrm{KOH}$ solution gives the highest recovery of ATX. When using lower concentrations of $\mathrm{KOH}$ solution than the obtimized ones, the saponification reaction may not be complete, whereas higher concentrations may lead to the decomposition of xanthophyll. Thus, the selected $\mathrm{KOH}$ concentration was $1 \%$ for ATX and $45 \%$ for Lut and Zea.

\subsubsection{Time and temperature of saponification}

After selecting the concentration of $\mathrm{KOH}$ solution, temperature and time of the saponification were optimized. Investigation result showed that saponification could complete at $60^{\circ} \mathrm{C}$ within 15 minutes. At lower temperatures and in shorter duration, the saponification process may not complete, while prolonging time and high temperatures can lead to degradation of xanthophylls.

Sample preparation procedure was described as the following:

Weigh $0.5-1 \mathrm{~g}$ of the sample into a $50 \mathrm{ml}$ centrifuge tube, then add $4 \mathrm{ml}$ of distilled water, mix them well together. Add the extraction solvent of $0.5 \mathrm{~g}$ ascorbic acid, $10 \mathrm{ml} \mathrm{MeOH}, 1 \mathrm{ml}$ of $45 \%$ $\mathrm{KOH}$ solution (for Lut, Zea) and 1\% (for ATX), $1 \mathrm{ml}$ THF, mix them all well. Heat the mixture up to $60^{\circ} \mathrm{C}$ in 15 minutes, then cool it down immediately in the ice tank. Extract the solution twice by n-hexane. Collect the upper phase, evaporate at $40^{\circ} \mathrm{C}$, disolve residual with $\mathrm{MeOH}$ and analysis on HPLC system.

\subsection{Validation of the analytical method}

- Blank sample: Dietary supplement samples that do not contain xanthophyll ingredients (marigold, corn flour, krill oil ...) were analyzed. A sample with no signal coinciding with the retention time of the analytical substance was selected as blank sample.

- Specificity and selectivity: analyze the mixed working standard solution, blank sample and blank sample spiked mixed working standard according to the selected chromatographic conditions. Compare the retention times and spectra of analyte in blank, standard and spiked samples (Figure 3). 

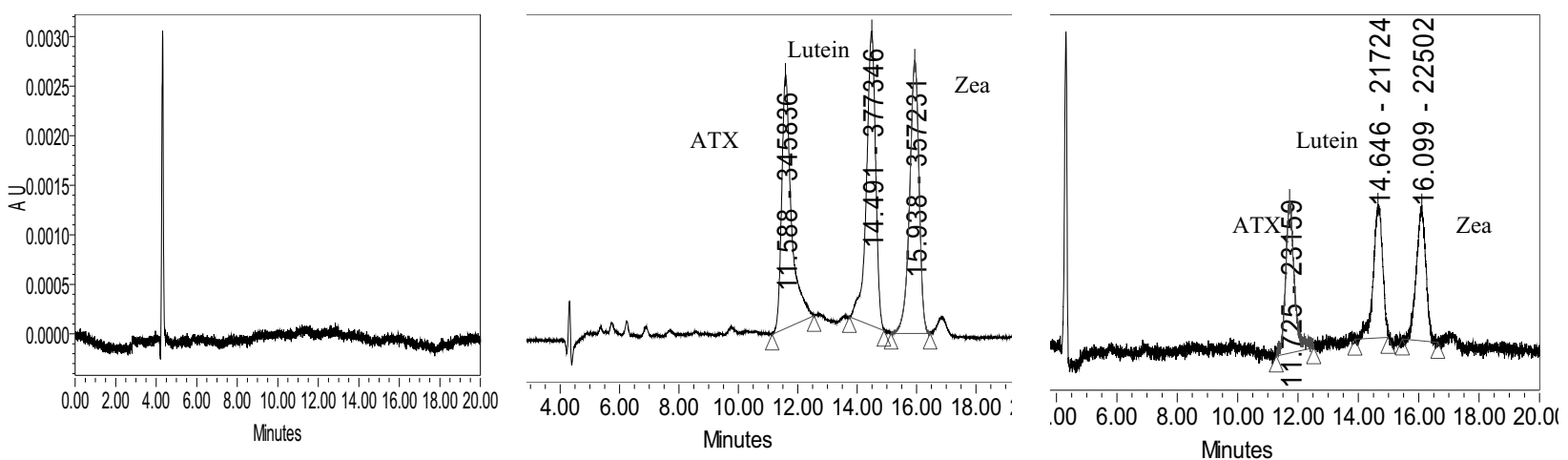

Figure 3. Chromatograms of blank, standard and spiked sample of ATX, Lut and Zea

The result showed that the retention time and spectra of ATX, Lut and Zea in spiked sample were the same as in the standard sample, there is no peak in the chromatography of the blank sample at the retention time of the analytical substance in the chromatography of standard sample. Thus, the method has been developed with specificity, high selectivity, suitable for simultaneous determination of ATX, Lut and Zea in dietary supplements.

Calibration curve: A series of standard solutions of ATX, Lut and Zea with the concentrations of about $0.5-10 \mu \mathrm{g} / \mathrm{mL}$ was prepared and analyzed on HPLC systems. Table 1 showed that the linear calibration curve was in the range of $0.5-10 \mu \mathrm{g} / \mathrm{mL}$ with the correlation coefficient $\mathrm{R}^{2} \geq 0,999$, and the bias $\leq 15 \%$. These all met the analysis requirements.

Table 1. Parameters of the calibration curve

\begin{tabular}{|c|c|c|}
\hline $\begin{array}{c}\text { Analytical } \\
\text { substances }\end{array}$ & $\begin{array}{c}\text { Calibration curve } \\
\text { equation }\end{array}$ & $\begin{array}{c}\text { Regression } \\
\text { coefficient } \mathbf{R}^{2}\end{array}$ \\
\hline ATX & $\mathrm{y}=35,073 \mathrm{x}-3,244.2$ & 0.9997 \\
\hline Lut & $\mathrm{y}=38,543 \mathrm{x}-9,588.8$ & 0.9993 \\
\hline Zea & $\mathrm{y}=36,915 \mathrm{x}-12,831$ & 0.9997 \\
\hline
\end{tabular}

Limit of detection (LOD) and limit of quantification (LOQ): in this study, LOD and LOQ values were determined by repeated analysis of 10 standard samples having low concentration (about 5 10 times to estimate the LOD value) of the analytes. LOD and LOQ were calculated with the following formula: $\mathrm{LOD}=3 \times \mathrm{SD} ; \mathrm{LOQ}=10 \times \mathrm{SD}$. The calculated $\mathrm{LOD}$ was assessed through the value of. If $4<\mathrm{R}<10$, then the test solution concentration is appropriate and the calculated LOD is reliable. Determined LOD and LOQ values indicated that the method can meet the requirements for the determination of xanthophyll active ingredients in real samples. The LOD and LOQ values were

Table 2. Summary the results of $L O D, L O Q$, recovery and repeatability

\begin{tabular}{|c|c|c|c|c|c|c|}
\hline $\begin{array}{c}\text { Sample } \\
\text { background }\end{array}$ & Parameter & \multicolumn{2}{|c|}{$\begin{array}{c}\text { Requirement according to } \\
\text { AOAC }[5]\end{array}$} & ATX & Lut & Zea \\
\hline LOD $(\mu \mathrm{g} / \mathrm{g})$ & \multirow{2}{*}{$\mathrm{R}$} & \multirow{2}{*}{\multicolumn{2}{|c|}{$4<\mathrm{R}<10$}} & 9.17 & 9.42 & 6.53 \\
\hline $\mathrm{LOQ}(\mu \mathrm{g} / \mathrm{g})$ & & & & 30.6 & 31.4 & 21.8 \\
\hline Recovery & $\mathrm{R} \%$ & $\begin{array}{l}\text { Concentration } \\
100 \mu \mathrm{g} / \mathrm{kg}-10 \mu \mathrm{g} / \mathrm{kg}\end{array}$ & $\begin{array}{r}80- \\
110 \% \\
\end{array}$ & $\begin{array}{l}82.2- \\
98.8 \% \\
\end{array}$ & $\begin{array}{l}80.9- \\
99.6 \% \\
\end{array}$ & $\begin{array}{l}91.2- \\
107 \%\end{array}$ \\
\hline \multirow[b]{2}{*}{ Repeatability } & \multirow[b]{2}{*}{$\mathrm{RSD}_{\mathrm{R}}$} & Concentration $0.1 \%$ & $\leq 5.6 \%$ & 3.16 & 2.60 & \\
\hline & & $\begin{array}{l}\text { Concentration } \\
0.01 \%\end{array}$ & $\leq 8.0 \%$ & & & 4.94 \\
\hline
\end{tabular}

54 | Vietnamese Journal of Food Control (No. 2-2019) 
summarized in Table 2.

- Recovery: ATX, Lut and Zea were added to blank sample at the concentration of $0.5 \mu \mathrm{g} / \mathrm{ml}$. The measurement was repeated 10 times to determine the recovery. Results were summarized in Table 2.

- Repeatability and reproducibility: Samples containing ATX, Lut and Zea were repeatly analyzed 6 times. Results were presented in Table 2.

Validation results revealed that the method has a high recovery of $80.9-107 \%$ and good repeatability (RSD $\leq 3.16 \%$ at concentrations of $0.1 \%$ and $4.94 \%$ at concentration of $0.01 \%$ ) for all three substances in the dietary supplement samples. This achieved the required criteria of AOAC. The values of LOD and LOQ were in the range of $6.53-10 \mu \mathrm{g} / \mathrm{g}$ and $21.8-31.4 \mu \mathrm{g} / \mathrm{g}$, respectively showing that the method had good sensitivity and was suitable to analyze the real samples.

\subsection{Application of method for dietary supplements}

The method was applied to analyze the xanthophyll content in health-protection food samples collected randomly in Hanoi. Analysis results indicated that the samples had different concentrations of xanthophylls, depending on their origin and intended use. The determined values were consistent with the declared content on the label (ranging from 90.6 to 102\%) with health protection food samples (Table 3).

Table 3. Xanthophyll content in health-protective food samples

\begin{tabular}{|c|c|c|c|c|}
\hline $\begin{array}{c}\text { Sample } \\
\text { name }\end{array}$ & $\begin{array}{l}\text { Analytical } \\
\text { substances }\end{array}$ & $\begin{array}{c}\text { Content } \\
\text { (mg/tablet) }\end{array}$ & Label claim & $\begin{array}{c}\text { Compare } \\
(\%)\end{array}$ \\
\hline \multirow{2}{*}{ TP-M1 } & Lut & 18.7 & 20 & 93.4 \\
\hline & Zea & 0.53 & 0.5 & 105 \\
\hline \multirow{2}{*}{ TP-M2 } & Lut & 4.82 & 5 & 96.5 \\
\hline & Zea & ND & - & - \\
\hline \multirow{2}{*}{ TP-M3 } & Lut & 15.4 & 15 & 102 \\
\hline & Zea & $\mathrm{KPH}$ & 0 & 0 \\
\hline \multirow{2}{*}{ TP-M4 } & Lut & 9.06 & 10 & 90.6 \\
\hline & Zea & $\mathrm{KPH}$ & 0 & 0 \\
\hline \multirow{2}{*}{ TP-M5 } & Lut & 9.72 & 10 & 97.2 \\
\hline & Zea & $\mathrm{KPH}$ & - & - \\
\hline TP-M6 & ATX & 9.30 & 10 & 93.0 \\
\hline TP-M7 & ATX & 13.9 & 15 & 92.7 \\
\hline TP-M8 & ATX & 9.06 & 10 & 90.6 \\
\hline TP-M9 & ATX & 20.0 & 20 & 100 \\
\hline TP-M10 & ATX & 4.70 & 5 & 94.3 \\
\hline
\end{tabular}

(ND: Not detected)

The ratio between Lut and Zea varied depending on the extracted source and the source of used materials. The method can be applied to determine ATX, Lut and Zea in helath protective food sample background. However, in order to assess the quality of products which are circulating in the market 
comprehensively, it is necessary to increase the number of samples. The method can be applied to analyze a large number of samples.

\section{CONCLUSION}

The chromatography conditions using C30 reversed-phase separation column and optimal sample preparation process were selected for simultaneous analysis of ATX, Lut and Zea in Dietary supplement sample background. Validation results showed that the method is noted with specificity, selectivity and high sensitivity. A wide range of linear concentration can be applied to analysis lots of samples having different concentrations of content. The repeatability, recovery and the internal reproducibility achieved the required criteria of AOAC. The analysis results of real sample were consistent with the values declared on the label (ranging from 90.6 to $102 \%$ ). However, in order to comprehensively evaluate the quality of products on the market, it is necessary to increase the number of samples. This could be an easy-to-implement method, which is reasonable to be applied widely in laboratories in Vietnam.

\section{REFERENCES}

[1] S. M. Moeller, P. F. Jacques, and J. B. Blumberg, "The potential role of dietary xanthophylls in cataract and age-related macular degeneration", J Am Coll Nutr, vol. 19, no. 5 Suppl, pp. 522S-527S, Oct. 2000.

[2] V. B. Pratheesh, N. Benny, and C. H. Sujatha, "Isolation, Stabilization and Characterization of Xanthophyll from Marigold Flower- Tagetes Erecta-L", Modern Applied Science, vol. 3, no. 2, p. p19, Jan. 2009.

[3] M. Guerin, M. E. Huntley, and M. Olaizola, "Haematococcus astaxanthin: applications for human health and nutrition", Trends in Biotechnology, vol. 21, no. 5, pp. 210-216, May 2003.

[4] K. T. Amorim-Carrilho, A. Cepeda, C. Fente, and P. Regal, "Review of methods for analysis of carotenoids", TrAC Trends in Analytical Chemistry, vol. 56, pp. 49-73, Apr. 2014.

[5] AOAC, "Appendix K: Guidelines for Dietary Supplements and Botanicals". AOAC OFFICIAL METHODS OF ANALYSIS, 2013.

\section{Tóm tắt \\ NGHIÊN CỬ XÁC ĐỊNH MỘT SỐ HOẠT CHẤT NHÓM XANTHOPHYLL TRONG THỬC PHẨM BẢO VỆ SỬC KHỎE BẦNG PHƯƠNG PHÁP HPLC-PDA}

\section{Mạc Thị Thanh Hoa, Nguyễn Thị Hồng Ngọc, Dương Thị Mai Hoa, Cao Công Khánh Viện Kiểm nghiệm an toàn vệ sinh thực phẩm Quốc gia}

Phương pháp phân tích HPLC sử dụng detector PDA đã được khảo sát và lựa chọn để xác định một số hoạt chất nhóm xanthophyll (astaxathin, lutein và zeaxanthin) trong thực phẩm bảo vệ sức khỏe (TPBVSK). Cột tách C30 và pha động đẳng dòng gồm ethyl acetat: acetonitrile $(12: 88, v / v)$ chứa $0,1 \%$ n-decanol cho thấy khả năng tách tốt nhất đồng thời ba chất. Các xanthophyll thường tồn tại ở dạng este được xà phòng hóa bằng dung dịch $\mathrm{KOH} 45 \%$ (với lutein và zeaxanthin) và $1 \%$ (với astaxanthin) ở $60^{\circ} \mathrm{C}$ trong 15 phút, sau đó chiết lại với $n$-hexan trước khi phân tích trên hệ thống HPLC. Kết quả thẩm định cho thấy phương pháp có độ đặc hiệu và độ chọn lọc cao, đường chuẩn tuyến tính trong khoảng $0,5-10 \mu \mathrm{g} / \mathrm{ml}$, độ lặp lại và độ thu hồi đáp ứng được yêu cầu phân tích theo AOAC. Phương pháp có thể áp dụng để phân tích các mẫu TPBVSK trên trị trường.

Tù̀ khóa: Xanthophyll, lutein, zeaxanthin, astaxanthin, thưc phẩm bảo vệ sức khỏe, HPLC. 